\title{
The Primitive Algae and the Flagellata. An Account of modern Work bearing on the Evolution of the Algae.
}

\author{
BY \\ F. FROST BLACKMAN, D.Sc., M.A., \\ Lecturer on Botany in the University of Cambridge. \\ With two Figures in the Text.
}

\section{INTRODUCTION.}

$\mathrm{D}^{\mathrm{c}}$

URING the last fifteen years our knowledge of the Algae, especially of the green Algae, has made rapid and continuous advance at an increasing rate. As a result we seem now at last to be in a position to grasp something of the phylogenetic relations of what once seemed a chaos of forms, and to correct by the evidence of these vestiges of the early stages of evolution of the vegetable kingdom our conceptions of plant nature and plant possibilities drawn previously only from the study of the higher types.

The publication ten years ago of Wille's account of the green Algae in the Pflanzenfamilien of Engler and Prantl ('90) may be held to mark a definite epoch, as his series of articles gathered together and skilfully displayed from the systematic point of view all the knowledge that was then available. This most excellent work has given a great impetus to further investigation, though we have now advanced beyond it in many respects.

The task that I have undertaken is to give some account of the work that has been accumulating on the green Algae

[Annals of Botany, Vol. XIV. No. LVI. December, 1900.] 
and their allies since Wille's articles were published. In this first article I propose to deal with such of this work as bears on the phylogenetic relations of the primitive forms of green and of brown Algae, and also to give an outline of their respective affinities with the Flagellata.

The literature of this subject is very much scattered, important work coming alike from Scandinavia, Russia, Hungary, and Italy; and as no general account of it has yet been published, I may be allowed perhaps to treat it at some length.

I have endeavoured to weave the different lines of work into one continuous account, so that inevitably I have had to ignore a certain number of opposed theories and to introduce some for which I alone am responsible.

The first section consists of an introductory sketch of the probable inter-relations of the forms which make up the Chlorophyceae, and leads to the conclusion that they are all derived from a Chlamydomonas-like organism. The second gives an account of the advance of our knowledge of this important genus, Chlamydomonas, during the last ten years. The third inquires into the evolutionary origin of this primary plant type, and contains a sketch of the group Flagellata. The fourth section is devoted to a phylum of green Algae, for which an origin quite apart from that of the Chlorophyceae proper is suggested. The fifth gives a brief account of the recently described primitive forms of the brown Algae, and of their probable evolution also from the Flagellata.

An outline of Wille's classification of the genera with which we shall deal is given on p. 649 , and this will serve as a starting-point for our treatment. Forms not mentioned by Wille are added in italics, and those which must now be moved elsewhere are placed in brackets.

The phylogenetic views propounded in the various sections have been worked into one general scheme, which will be found on pp. 684, 685. The lower part is occupied by the Flagellata, and the dotted zone right across includes the forms on the border line, the position of which is still open to question. 
An attempt is made to indicate the 'grade' of evolution by position considered vertically, and a horizontal line is drawn across each phylum where it appears to come to an end.

\section{PROTOCOCCOIDEAE (Wille emend.).}
Chlamydomona-
$\left\{\begin{array}{c}\text { Chlamydomonas, Carteria,Sphaerella, } \\ \text { Chlorogonium }\end{array}\right.$ Phacoteae
Polyblepharideae
Phacotus, Pteromonas
I. Volvocaceae
5. Protococcaceae $\left\{\begin{array}{l}\text { Endosphaereae } \\ \text { Halosphaereae } \\ \text { Characieae }\end{array}\right.$
\{ndosphaera, Chlorochytrium, Phyl- lobium, Chlorococcum
Halosphaera
$\{$ Characium [Ophiocytium] [Scia- dium] [Peroniella]
6. Hydrodictyaceae
$\{$ Hydrodictyon, Pediastrum [Coelas- $\{$ trum] [Sorastrum]
2. Tetrasporaceae
Chlorangium, Tetraspora, Radiofilum $\left\{\begin{array}{l}\text { [Mischococcus], Chlorodendron } \\ \text { [Dictyosphaerium] [Oocardium] }\end{array}\right.$
3. Chlorosphaeraceae
4. Pleurococcaceae
Chlorosphaera
$\{$ Pleurococcus, Scenedesmus, Raphi- $\{$ dium [Stichococcus]

\section{CONFERVOIDEAE.}

7. Ulvaceae

8. Ulothrichaceae

9. Chaetophoraceae

I0. Mycoideaceae

I3. Coleochaetaceae

16. Sphaeropleaceae
Monostroma, Ulva, Letterstedtia

\section{\{lothrix, Hormidium [Conferva]} [Bumilleria], Microspora

$\left\{\begin{array}{l}\text { Chaetophoreae } \\ \text { Chroolepidae } \\ \text { [Phaeothamnieae }]\end{array}\right.$

Stigeoclonium, Pseudopleurococcus

Trentepohlia

[Phaeothamnion]
I2. Oedogoniaceae

I5. Gomontiaceae

\section{Section I. Chlorophyceae.}

The subdivision of this group which is generally observed is that employed by Wille, into Siphoneae, Confervoideae, and Protococcoideae. The first of these groups is a natural 
one based on the coenocytic structure of the thallus, and will probably remain long unchanged. The other groups are not natural, and must before long be abandoned.

The Confervoideae contain those types of organization which are filamentous or membraneous, and which are universally accepted as forming one step in phylogenetic ascent from the lowest unicellular Algae to the higher plants.

The Protococcoideae seem to have been first segregated as a heterogeneous remainder of primitive forms left after the characterization of the other two groups. In the Protococcoideae we find all grades of sexual reproduction up to oogamy (Volvox), and many different types of vegetative organization: motile single cells (Chlamydomonas), non-motile single cells (Endosphaereae), loose indefinite colonies (Tetraspora), definite coenobia of motile (Volvox), or of non-motile cells (Colastrum), and even coenobia of coenocytes (Hydrodictyon). Some of these organisms live entirely by vegetative division, and others are characterized by never dividing vegetatively. This chaos of forms resolves itself, when studied inductively, into some ten more or less natural groups (sub-families of Wille); cf. p. 649 .

Among this group of families there are three divergent vegetative tendencies, which furnish, I think, the natural broad phylogenetic lines on which to arrange the different types. These I would distinguish as follows :-

The first of these tendencies, the Volvocine, is towards the aggregation of motile vegetative cells into gradually larger and more specialized motile true coenobia.

The second, or Tetrasporine, is towards the formation of aggregations by the juxtaposition of the products of septate vegetative cell-division to form non-motile organisms of increasing definiteness and solidarity.

The third, or Endosphaerine, tends towards the reduction of vegetative division and septate cell-formation to a minimum. The organisms on this line are strictly unicellular and nondividing when primitive; unseptate coenocytes when more advanced in type. 
Let us now examine these three tendencies and the different organisms which manifest them in order to see what their origin may have been and whither they lead.

I. The manifestation of the Volvocine tendency is comprised within the single sub-family Volvoceae (Wille). This consists of a series of genera which are practically coenobia of cells of the Chlamydomonad type (see Section II). The other sub-families of the Volvocaceae, except Scyaminae, are like Chlamydomonas, strictly unicellular motile individuals and in the Volvoceae we find evolving from them, by the aggregations of such units, the ascending series of forms of Gonium, Pandorina, Eudorina, Placodorina, and Volvox. Volvox is undoubtedly the highest of these motile coenobia ${ }^{1}$, and has reached a very high degree of organization in that it has parts specialized for reproduction and a true nonreproductive 'soma.' The sexual reproduction is oogamous, and Coleochaete alone among the green Algae exhibits a higher method. Along this line of evolution nothing higher than Volvox exists, and this tendency comes to a blind end within the Chlorophyceae, or indeed within its lowest groupthe Protococcoideae-as generally understood.

In its grade of organization and of reproduction Volvox is on a level with high forms in the Siphoneae and Confervoideae, and is, I think, much too highly evolved to be included in a family of primitive forms. Yet it would be impossible to remove it from the Protococcoideae without taking out also the primitive Chlamydomonas, so closely are they linked by intermediate forms. This alone shows how unnatural is this 'grade' group.

2. The second tendency is exhibited in the Tetrasporaceae, where vegetative cell-division is the chief method of multiplication, and in the Pleurococcaceae, where it is the only

\footnotetext{
1 By a 'coenobium' is to be understood, structurally, a definite colony of cells which is reproduced as such from a mother-cell, and which never multiplies its number of units when once thus formed, so that all its cells belong to the same generation. Coenobia exhibit very different degrees of solidarity, individuality, and differentiation.
} 
one. In the simplest types the cells so formed separate from one another, and so no advance in organization follows. In higher forms the sister-cells are united by mucilage, by remains of the mother-cell-wall, or in other ways, so that colonies arise.

The Tetrasporine plants are always non-motile in their vegetative condition, and some of the most primitive, as Chlorangium, are little more than sessile attached Chlamydomonads, which develop by dividing vegetatively into new cells, that remain attached to the mother-cell-wall and build up thus a little colony. Before this reaches any size, however, the building-up stops, and the cells-as zoospores-revert to the ancestral motile type and swarm off to new spots.

Like the Volvocine tendency then, the Tetrasporine has its origin in the motile unicellular Chlamydomonads. The one of these Tetrasporine aggregations that has been most successful from the biological standpoint is the filament, and as transition forms we find filaments (Stichococcus, Bumilleria, Hormidium) which are not yet possessed of much solidarity, and which easily separate into single cells or short lengths. Numerous other forms of colonial cell-unions are found in these families, but nothing higher appears to have been evolved from any of them. These may perhaps be looked upon as experimental types of aggregation which have failed in the struggle for existence. The filament, however, has been eminently a success, and the large group of filamentous and membraneous thalloid forms constituting the Confervoideae bears witness to this.

From the Confervoideae, as is universally admitted, has been evolved the whole series of higher plants, Bryophyta, Pteridophyta, and Phanerogamia, so that the tendency seen in the Tetrasporaceae to form, by septate cell-division, thalloid aggregates of increasing solidarity is the one responsible for the structural possibilities of the higher plants.

A line of separation between the Protococcoideae and the Confervoideae, that is the separation of unicellular organisms from filamentous organisms, is found to be untenable now that 
investigations on the effect of varying external conditions on the form and function have made such rapid progress.

Klebs ('96) was the pioneer in this as in many other important algological departures, and from his work it appeared that under certain definite conditions filamentous forms may break up into small aggregates or into single cells.

To Klercker ('96) we owe an absolute proof of the truth of this, by observation of two species of the genus Stichococcus. Since the early investigations of Nägeli ('49) a unicellular Alga, Stichococcus bacillaris, had been recognized, which had the shape and method of vegetative division of a large, thick Bacterium. It has, however, one clear green chloroplast attached to the side of the cell and leaving the two ends colourless. No zoospores, gametes, or resting-cells occur, so it clearly found a place in the Pleurococcaceae. A filamentous Alga with rather similar cell-contents had been variously named as Ulothrix subtilis or Hormidium subtile, and though nothing was known of its methods of reproduction, its unbranched filamentous form entitled it to a place in the Ulothrichaceae.

The similarity of the cytological structure suggested some affinity between these forms, and Klercker has succeeded in showing that each of them can exist in a filamentous state and a unicellular 'coccoid' state. He proves this by successive drawings under the microscope, showing the individual cells of the filament separating from one another and drifting apart with rounded ends to continue existence and multiplication in the coccoid state (Fig. I4 $a$ and $b$ ). The cytological characters are retained unchanged through the transition, and these two species, S. subtilis and S. bacillaris, are clearly thus distinguishable.

Normally these two species exist, one (S. bacillaris) as separate single cells, and the other (S. subtilis) in the form of filaments, so that we have a genus with one species in one main group (Confervoideae), and the other in another (Protococcoideae). Nothing could better exemplify the unnaturalness of the distinction. 
This easy reversion to a unicellular form shows how the filamentous type may have been evolved by adhesion of the products of vegetative division. The unbranched primitive filamentous Confervoideae are no doubt polyphyletic, and it seems natural to associate the main forms, having zoospores and gametes, with the Tetrasporaceous unicellular type, and forms not having them with the Pleurococcaceous type, as in the case of Stichococcus.

Wille ('90) and others represent the membraneous Ulvaceae as the root-family of the Confervoideae because the passage from Tetraspora to this family is so easy. The derivation of the filamentous Ulothrichaceae from the Ulvaceae seems to me a mistaken idea, when a direct origin for them from those Tetrasporaceae which tend in a filamentous direction is so much simpler. Radiofilum, Bohlin ('97), G. S. West ('98), suggests such a form, consisting of a string of cells imbedded in a mucilaginous matrix which has the shape of an unbranched filament (Fig. 14). The Ulvaceae may be regarded, then, as a side branch from the Tetrasporaceae, ending blindly in the highly differentiated form Letterstedtia.

The case of Pseudopleurococcus, Snow ('98), is another of those in which by change of conditions an Alga that is normally unicellular passes into a branched filamentous state. Here the two forms taken independently would be placed in the branched Chaetophoraceae and in the Pleurococcaceae respectively, which is a wider separation than had been made between the forms of Stichococcus.

The characterization of families by external form is, in this group, quite unpermissible ${ }^{1}$, and the present subdivision into families, representing different grades of vegetative morphological complexity, can only be regarded as temporary until our increasing knowledge enables us to form phyletic families.

\footnotetext{
${ }^{1}$ Senn ('99) has shown that by appropriate conditions the coenobia of some Pleurococcaceae-Coelastrum, Scenedesmus - can be made to give rise to single isolated vegetative cells which lack the formal characters of the cells in the coenobia. Fig. I4, Coelastrum reticulatum, $a$, cells united by mucilage arms as in the coenobium; $b$, armless free cells.
} 
3. We must now return to the third line of evolution. The Endosphaerine tendency is exhibited by the Protococcaceae and Hydrodictyaceae, but we do not find here clear serial arrangement of stages in its development. The family Protococcaceae is an aggregate of diversified forms, and almost all the genera of one sub-family-the Characieae-have been removed elsewhere (cf. Section IV), while Halosphaera has a sub-family to itself. In all, however, we find complete absence of vegetative division, and individuals are only multiplied by formation of zoospores or of gametes. The Endosphaereae are mostly strictly unicellular, but Phyllobium shows some coenocytic tendencies.

The Hydrodictyaceae as revised contain only complex forms, which are coenobia of coenocytes, and never exhibit septate vegetative division; but the affinities of this specialized family with its neighbours are not yet clear. Coelastrum, however, is known to multiply its coenobia by vegetative division; but Senn ('99), in a paper, the most important parts of which will be dealt with subsequently, has shown clearly that Coelastrum (and with it Sorastrum, presumably) must be transferred to the Pleurococcaceae, leaving only Pediastrum to be grouped with Hydrodictyon. In the family thus restricted the coenobia in both genera arise by the apposition of motile zoospores within a mother-cell-wall, while all the coenobia of the Tetrasporaceae and Pleurococcaceae are formed by vegetative septate division of a mother-cell. Thus the contrast of tendency on these two diverging lines of evolution which I have been maintaining becomes by this rectification still more pronounced.

With very high probability it is this Endosphaerine tendency which, carried further, has given rise to the well-defined type of the Siphoneae, consisting of a thallus which, though essentially coenocytic, is structurally unicellular and lacks the solidity acquired by septate cell-division. The possibilities of this type of aggregation are considerable, and it has given rise to many very varied forms; but as with the Volvocine type, nothing appears to have been evolved from it of higher 
status than an Alga. While the Tetrasporine tendency has given rise to all the higher green plants, the Endosphaerine has only succeeded in producing the elaborate but puny mockery of them which we find in Caulerpa.

The simplest forms exhibiting this tendency seem to be derived also from the motile unicellular Chlamydomonas type by loss of motility and by dependence on zoospore-formation in place of vegetative division, which is in direct opposition to the line of development of the Tetrasporaceae.

All the three lines of evolution which we have now considered seem clearly to diverge from Chlamydomonas, and this motile organism must be regarded as the real primitive form of green plant.

Beyond the glamour which this position throws over the Chlamydomonads, an immense importance should be attached to obtaining as complete knowledge as may be possible about the biology, structure, and reproduction of form, in which we have the vegetative potentialities of all the different types of green actualities which have filled the earth and attained justification by natural selection.

\section{Section II. Chlamydomonas.}

This section will be devoted mainly to the consideration of the genus Chlamydomonas. This is so much richer in species, in varieties of life-history, of structure and of reproduction, than the other genera in its family, that many monographs have been devoted to the investigation of it ; and as knowledge of the Algae increases, the tendency is always towards emphasizing the importance of this genus.

A typical Chlamydomonad as Chl. Steinii (Fig. I3), Goros., consists of a single oviform cell, which swims freely by two cilia projecting from the advancing narrow end. It has a clearly defined cellulose wall, within which is the solid protoplast. The greater part of the cell is occupied by the single large basin-shaped chloroplast, a small region of colourless protoplasm being visible at the anterior end only. To this 
specialized non-granular protoplasmic end are attached the cilia, protoplasmic in nature, which perforate the cell-wall. Here also are the two small contractile vacuoles which, pro-
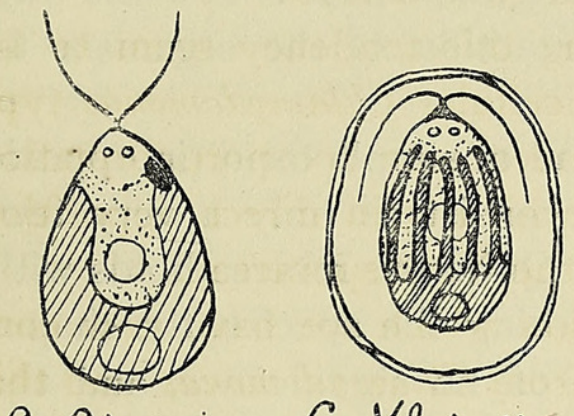

C Staini

C. Kleinii
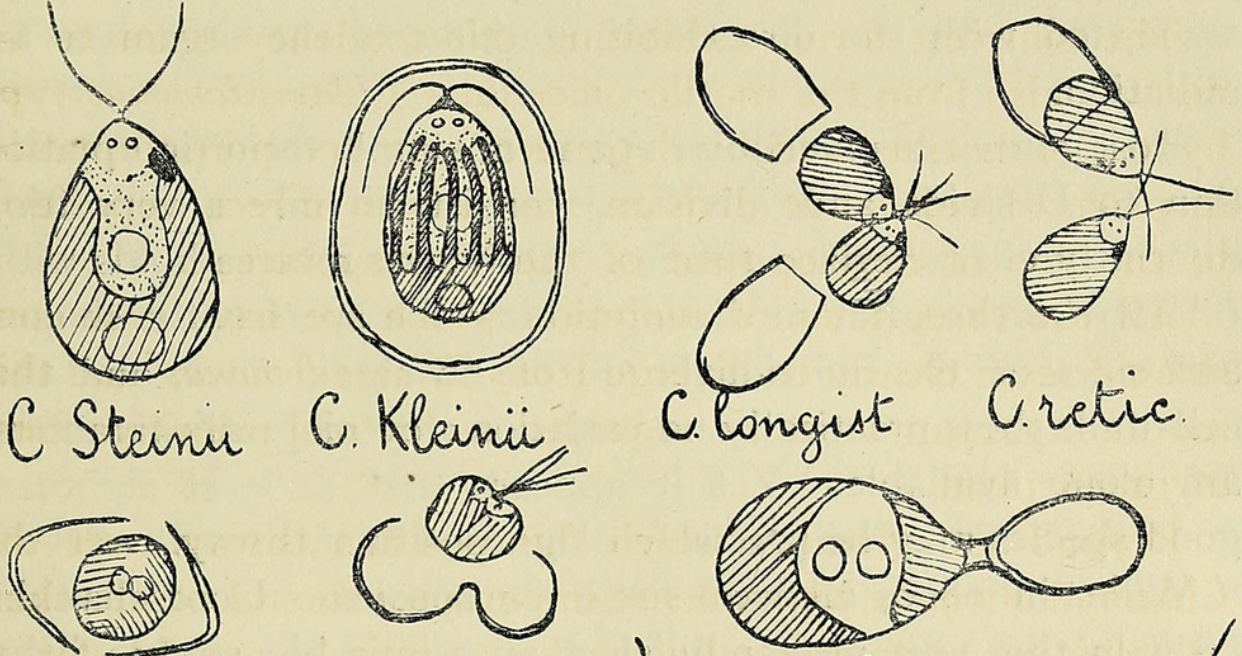

Cretic

C.Ehrent. C.multif.
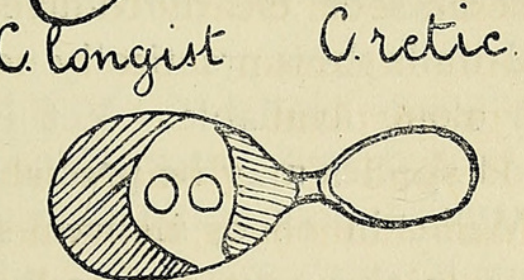

C Brauni

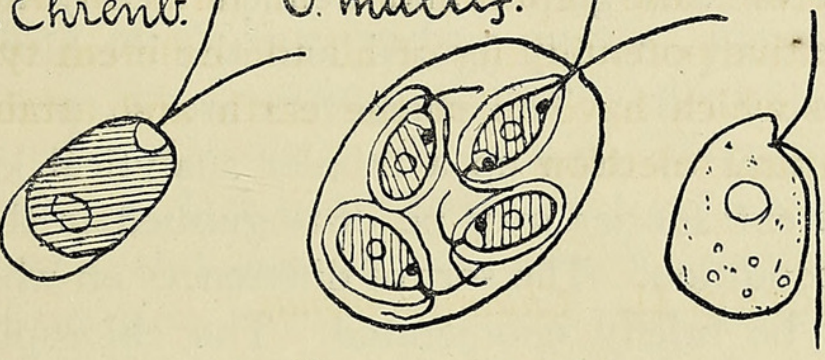

Cmedia Sph. Butschlii Bodo Euglena

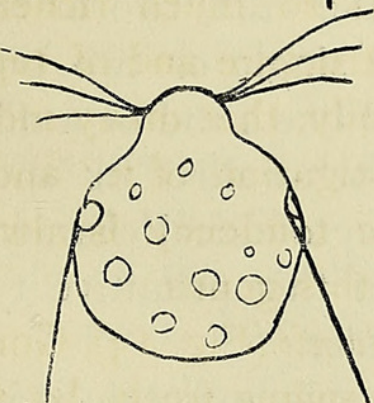

Hexamitus
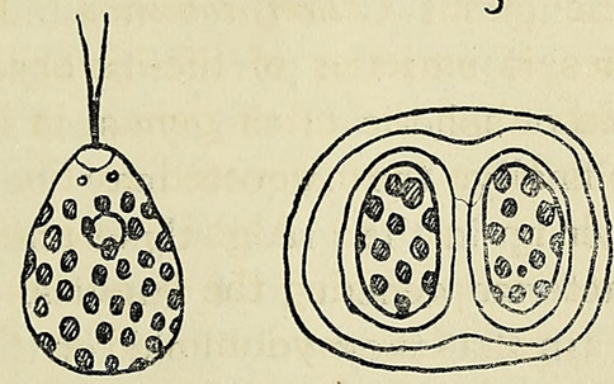

Vacuolaria

Fig. I3.

bably excretory in nature, contract and recover once a minute or so. The chloroplast contains one large pyrenoid of a proteid nature in the centre of its thick basal part. The 
hollow of the chloroplast contains granular protoplasm in which the nucleus is situated. Finally, somewhere on the periphery of the anterior half of the protoplast is a bright red pigmented disk, the eye-spot or stigma, which is in some way associated with the directional reaction of the organism to radiation.

Most genera of unicellular Algae of simple form (in opposition to Desmids and Diatoms) consist of only a very few, difficultly characterized species. Quite the reverse holds with Chlamydomonas, but in distinguishing the species, the shapes and sizes of the individuals are of no significance, and the cell-walls show practically no variation : cytological characters are alone available. Yet it appears that at least eighteen good species may be precisely diagnosed in this way.

Wille, in 1890 , allowed some six species. Goroschankin ('91) in the next year published an admirable study of the specific characters in this genus, and defined clearly nine species. These were all carefully figured, and the life-history was followed in every case. The characters are so precise that the author is able to draw up a tabular analytical key, by which the different species may be distinguished in their motile vegetative condition. The sort of differences on which this is based may be briefly enumerated. The chloroplast may be solid or reticulate, ring or basin shaped; the contractile vacuoles, two or three in number; the cilia, two or four, short or long; the pyrenoids, absent or single or two, boatshaped or spherical ; the eye-spot shaped like a rod or a disk; and, finally, the zygote may be smooth-walled or spiny. Higher up in the green Algae uniform cytological characters characterize genera and families, but in this primitive type we learn that they only hold for the species.

Francé, in 1892 , in a revision of the genus, maintained that these cytological differences were not really constant, and proposed to reduce largely the number of good species. No experimental evidence of the passage of one form into another was, however, presented.

Schmidle, in 1893 , described a very interesting new species, 
Chl. Kleinii. He cultivated this under various different conditions, and found that its well-marked cytological characters remained quite constant. This species is further of interest because it shows less of the characteristic motility in its vegetative condition than any other member of the Volvocineae. It only swims freely for a very short time, never dividing while free, and then comes to rest on some substratum, and surrounds itself with a mucilaginous excretion, which may leave the cilia still projecting or may include them. In this condition, by repeated transverse bipartition, large but very loosely coherent aggregates of individuals are formed, each within its own mucilaginous envelope.

Some such resting Palmella-like condition occurs as a phase in the life-history of all the Chlamydomonas species, but in this form it is the preponderating condition, and brings us very close to the types found in the Tetrasporaceae, which are all non-motile throughout their vegetative condition.

Dill, in 1895 , published a most important paper which proved the constancy of the cytological specific characters for a large number of species of Chlamydomonas. At Kleb's suggestion Dill cultivated all the species he could collect, in Knop's solution of various strength, in water, in sugar solution, and on damp moss. He found that variations might thus be produced in the size of the individuals and in the thickness of their cell-walls, but that the cytological characteristics given above remain unchanged; with this solitary exception, that with Chl. longistigma nutritive salt solution causeselongation and frequently bipartition of the pyrenoids, so that four are present in place of the normal two.

Six of the species Dill cultivated were newly discovered by himself, which brought the number of well-established species up to fifteen, all of which can be recognized in their vegetative condition. This is a very remarkable result when we consider that with higher genera of Algae, Spirogyra, Oedogonium and other filamentous forms rich in species, it is only from the reproductive organs that the species can be certainly diagnosed. 
This specific constancy in the most primitive type is in strong opposition to the idea of wide polymorphism brought forward by Hansgirg, Chodat, and Borzi, which associates different genera, and even members of different families, in the life-history of one individual.

Dill's paper contains further work of importance on the nature of the divisions by which the different species multiply vegetatively. We shall find, when discussing subsequently the relation of the Chlamydomonads to organisms of a decidedly animal character, that it is a marked characteristic of the division-process in the latter that this takes place in the antero-posterior direction, being generally a slow constriction starting at the two ends and proceeding to the centre.

In organisms of a decidedly vegetable character, division is a more rapid process, nearly simultaneous throughout the protoplast, and the first division nearly always takes place in a transverse plane.

In Chlamydomonas, Dill finds that, while the majority of species divides by a rapid transverse division, yet some divide by a first longitudinal division, not however of the nature of a slow constriction. The real interest of these two directions of division lies in this, that it is just those species which on evidence drawn from their sexual reproduction appear most primitive (i. e. least decidedly vegetal in character) that exhibit this more animal characteristic of a first longitudinal division. Between the species which divide first transversely and those which divide first longitudinally, Dill discovered a small interesting group of species in which a transitional condition occurs. In these forms the first sign of division is in the longitudinal direction, but the protoplast gradually rotates inside the cell-wall so that the division-plane separating the two sister-cells becomes transverse.

Still more striking than the variation in cytological characters found in the single genus Chlamydomonas is the variation in the sexual reproductive process. In every other genus of plants throughout the vegetable kingdom, however various the specific forms and biological characters, it is 
found that the sexual reproductive process is in essentials constant and uniform for the genus, but here it is quite different.

Chlamydomonas affords an unique opportunity of acquiring a clear idea of the relation of the conceptions, genus, and species at the very foot of the phylogenetic tree, and we shall see that characters which are of ordinal and cohortal value very little higher up are here merely of specific value.

To illustrate this, let us consider the different types of sexual reproduction within this single genus. Isolated observations are found in the works of Ehrenberg ('38), Stein ('78), and others, but the first comparative study of the sexual process was made by Goroschankin ('91). In Chl. Steinii and the majority of species the contents of the vegetative cell divide by repeated bipartition into sixteen or thirty-two small planogametes. These are ciliated ovate bodies, and though much smaller than, yet of the same character as the vegetative body, except that they have no cell-wall. They escape by rupture of the mother-wall, and after swarming conjugate in pairs. As they are all of one size the union is isogamous, and a round zygote results, which surrounds itself with a thick wall and rests. This is a parallel procedure with that found in the higher Protococcoideae. In some other species the planogametes are provided with walls when first formed, and thus are quite like vegetative cells but for their size. This formation of walled planogametes is absolutely unknown in any higher plant than Chlamydomonas, and even in this genus is only found among the most primitive species, i. e. those which begin the vegetative division with a longitudinal bipartition. Before these planogametes actually conjugate they must get rid of their cellwalls, and for this process we find a continuous series of forms.

Thus with Chl. longistigma (Fig. I3) the walls of both the gametes about to unite are thrown off while the cells are still some distance apart; with Chl. reticulata (Fig. I3) one gamete seems to throw off its wall before the other, so that at conjugation only one quitted wall is to be seen; with 
Chl. Ehrenbergii (Fig. I3) the walls are thrown off at the moment of union of the gametes, so that the two shells are found close to the resulting zygote; and finally, with Chl. multifilis fusion advances so far before the walls are actually discarded that the walls are left fused together at one part to form a single shell.

We have thus a series of forms, of which the last-mentioned is presumably the most primitive; from this we proceed up to gametes devoid of walls from their first formation.

The lower end of this remarkable series would be completed if we had a form in which the gametes conjugated by uniting inside their walls without throwing them off at all. Goroschankin ('90), in a separate and very complete paper, has shown that this is exactly what occurs in Chl. Brannii (=Chl. pulvisculus, Stein). In this species (Fig. I3), however, the walled gametes are of different sizes (heterogamous), and in their later stages non-motile by loss of their cilia, so that this form cannot take its place directly at the lower ends of an isogamous series. The smaller (male) gamete is about half the size of the female one; when they have swarmed close together the cilia are lost, and processes of the wall are put out at adjacent spots. These meet and fuse and form a canal, through which the contents of the smaller gamete pass over into the larger one. A wall is then formed in the canal, and the protoplasts of the two gametes fuse completely and form a zygote inside the wall of the female gamete. Occasionally several male gametes attach themselves to one female, but the contents of one only of them passes into the female. The similarity of this process with that occurring with the nonmotile cells of Spirogyra and other conjugates is most remarkable, and it has been suggested that this is of real phylogenetic significance. At present we need only dwell on the variety of process found in this single genus from one extreme of the union of heterogamous walled aplanogametes to the other of the union of isogamous naked planogametes.

In addition to these forms Klebs ('96) has described a new species, Chl. media (Fig. I3), which shows a slight variation 
from the type of Chl. longistigma in that the gametes before throwing off their walls begin to contract away from them at the posterior end and remain in this preliminary condition for some time, thus clearly marked as gametes. Klebs makes acute use of this visible character in his well-known experiments on the effects of conditions in inducing vegetative or sexual activity.

When a vegetative Chlamydomonas-cell is about to divide to form new individuals (the usual number in one mother-cell being four), it usually loses its cilia and becomes motionless, but this is not always so, and a mother-cell occasionally may be seen still moving after the four daughter-cells within it have acquired their new cilia. The movement is effected by the old cilia being still in continuity with the hinder end of the protoplast of the nearest daughter-cell. Such a condition (Fig. 13) is regular in one species of the closely allied genus, Sphaerella Bütschlii, see Blochmann ('85).

At some stage in their life-history all the species of Chlamydomonas are considered to pass into what is known as the Palmella-condition, where the cilia, eye-spot and contractile vacuoles may be lost and the resulting non-motile cells secrete mucilaginous walls within which they slowly divide to form irregular aggregates encircled by swollen traces of successive mother-cell-walls. Unfavourable conditions tend to produce this condition which was at first taken to be a separate genus. We have apparently in this condition the beginning of a vegetative existence in the narrower non-motile sense such as we find predominating in the Tetrasporaceae. At intervals in the life-history in this family the cells escape from their walls, put out cilia, and return to the motile condition as zoospores.

Formation of zoospores is then nothing but reversion to an ancestral type of vegetative existence for a biological advantage, and all the vegetative existence of the higher Algae is phylogenetically a new intercalation into the lifehistory of the motile Chlamydomonad which is permanently in the zoospore condition, though walled, and in which 
zoospore-formation and vegetative cell-division are one and indistinguishably the same thing.

The cytological processes had been but little investigated till Dangeard ('99) contributed a long paper dealing with these in the Chlamydomonads and with the behaviour of the nucleus in division and in sexual fusion. This constituted a very distinct advance in our knowledge.

One of the points investigated is the relation between the protoplasm of the chloroplast and that of the rest of the cell in those types which are only just removed by evolution from colourless Flagellates. Chlorogonium euchlorum has the characters of a transitional form, and the earliest writers held the chlorophyll to be diffused through the cytoplasm generally, but Francé ('97) described differentiated discoid chloroplasts or a few spiral bands round the cell. Dangeard shows by skilful staining that there is but one chloroplast, as in the rest of the family, but that this is perforated with masses and strands of the central colourless protoplasm so that it may appear cut up into bands or disks.

Chlorogonium euchlorum seems to be very variable and erratic in its cell-characters, for the pyrenoids may vary from four to thirty-two, contractile vacuoles may be present in large numbers, and finally the individuals from one special habitat really seemed to have diffuse chlorophyll, colouring all the cell except a fragment at each end. The author is unable to suggest the cause and significance of these variations in one species of a family otherwise characterized by the constancy of its specific cytological characters.

The structure of the nucleus in the Chlamydomonads can be very clearly made out and all stages of karyokinetic division followed, and the chromosomes counted. The number for each species (10-30) is fairly constant.

Non-karyokinetic division of the nucleus was observed only in Chlorogonium, and this quite exceptionally. As this is generally held to signify degeneration, the author thinks it probably a prelude to death or sexual reproduction in this case. 
A large part of the work deals with facts and theories as to protoplasmic and chloroplastic structure, among which there is signalized the discovery of a blepharoplast at the insertion of the cilia in Chlorogonium.

In studying the development of the zygote the author finds that the two chloroplasts fuse to form one, unlike their behaviour in Spirogyra (Chmielevsky, '90), and that sometimes two pyrenoids may actually fuse together though this is not the rule.

The paper concludes with a theory of sexuality, according to which the sexual reproduction in these primitive forms in which sexuality is only just evolved, is of the nature of a 'reciprocal autophagy.'

This theory regards gametes as in origin ordinary vegetative individuals which have for certain reasons 'run down' so to speak, and have acquired by natural selection sexual affinity which corresponds to a sort of hunger by which they are driven to fuse with, i. e. consume, some other individual by which they gain nutritive substance, and also energy perhaps of some special nature as well as the stored chemical energy. This enables existence to be carried on briskly again.

This way of looking at the matter fits many of the facts discovered by Klebs, such as that nutritive salt-solutions tend to avert sexual reproduction and bring on either parthenogenesis or a return to vegetative existence.

The theory also demands that in primitive sexuality the fusing nuclei shall have the same number of chromosomes as the vegetative individual, and this is found to be so among the Chlamydomonads. The necessary reduction probably takes place on the germination of the zygote.

Among more highly evolved plants the specializations to secure sexual reproduction mask the clearness of this interpretation, as when nuclear reduction becomes postponed in the sporophyte until the gametophyte is about to be produced. Many other phenomena of sexuality are brought into line with Dangeard's point of view in quite an interesting way. 
We see from this section that though Chlamydomonas is the most primitive of Algae, yet it has an elaborate organization which should be accounted for by its descent; so in the next section we shall seek for light upon the evolutionary origin of this foundation-stone of the vegetable kingdom.

\section{SECTION III. Flagellata.}

Until recent times investigators of the lower organisms strove to find a dividing line between those that ought to be classed as plants and those that must be regarded as animals. Attempts to base such a distinction on any single testcharacter resulted in groupings that were most obviously unnatural. The last and best of these characters in which hope was put, was the distinction between the methods of nutrition in the two kingdoms, but this also fails as a clue to a natural separation ${ }^{1}$.

The only scientific method of procedure is now recognized to be the inductive one. By this the organisms, such as they may be found to be, are grouped together by a consensus of their characteristics in small natural groups, and these again into larger aggregates. This, of course, in itself is by no means an easy matter, and until it had been approximately accomplished it could not be determined how far a line could be drawn between the two kingdoms without doing violence to these induced natural groupings.

Knowledge, however, gradually comes to hand, and it is certain that by no set characteristics can the distinction between plant and animal be pushed right down as a fundamental cleavage-line without separating otherwise closely allied genera and doing similar violence to natural groupings.

In the sea, of low forms of life (Protista) that intervene between the contrasted and undisputed plant and animal kingdoms, certain groups have been found by inductive investigations to stand out well characterized. The most striking of these, to the botanist at least, is that of the

${ }^{2}$ A few forms with well-developed chromoplasts, as Chromulina, ingest solid food. 
Flagellata (sens. Klebs) and for this reason, that it contains just those organisms which approach closest to the lowest plants. Any battle to extend or restrict the territory of the plant must be fought out on the boundary to be drawn between the Algae and the Flagellata.

It is thus impossible to treat critically the lower green Algae without giving some attention to the groups of Flagellata which adjoin them. That we are able to consider these in any satisfactory way is due almost entirely to Klebs, and the masterly quality and immense quantity of his work make a deep impression on any one who goes into the subject. In $\mathrm{I} 893 \mathrm{Klebs}$ published his elaborate study of the organisms of this group; and this account serves as a starting-point for all future work and speculation. In these ' Flagellatenstudien,' Klebs maintains that this name corresponds to a natural group of organisms having certain characters in common. The critical characters are those relating (1) to structural organization, (2) to the manner of vegetative division, and (3) to the nature of the resting stages.

I. Broadly speaking the Flagellates have the same type of organization as the lowest Algae-the Chlamydomonadsnamely, a motile, more or less oval, solid protoplasmic body with a central nucleus and a specialized anterior end with two or more cilia and contractile vacuoles. The cell may be colourless or have green or brown chromatophores.

In the peripheral envelope, however, we find a difference. Outside the protoplasm there may be a dead mucilaginous envelope, but there is no cell-wall as in the lower Algae. The protoplasm may be limited by a very thin specialized layer (periplast) or by a thick special layer (plasma-membrane) as in Euglena, but these are integral parts of the cell and divide with it, unlike a true cell-wall. Further, starch is not found, chloroplasts are usually discoid, and the nature of the wall permits amoeboid movements to occur.

2. The division usually takes place in the motile stage, and is always longitudinal and of the nature of a slow constriction into two halves starting from the fore end. 
3. The resting cells are cysts formed vegetatively, and zygotes do not occur, as no sexual distinction or reproduction occurs in the Flagellata.

Five subdivisions of the Flagellata are proposed by Klebs.

I. Protomastigina, including the small simplest forms which have only a periplast, are abundantly amoeboid, and always colourless. These absorb food either by their whole periphery or only at the fore end, where however there is no definite mouth. (Bodo, Fig. I3.)

II. Polymastigina, larger colourless forms of rather similar organization and mostly taking up solid food at definite places with a mouth, but this never at the fore end. This group has no plant affinities at all. (Hexamitus, Fig. I3.)

III. Euglenoidina, large forms with well-developed plasmamembrane, 'metabolic' but never amoeboid. At the fore end is a mouth through which the cilia are attached to the wall of a vacuole (Wager, '00). The body is colourless or with green disk chromatophores. The nutrition may be holophytic, saprophytic, or animal. (Euglena, Fig. I3.)

IV. Chloromonadina, body somewhat amoeboid and without plasma-membrane, numerous discoid (yellow-green) chloroplasts. The nutrition is holophytic and division takes place in a mucilage-invested resting stage. Only two or three genera of this type are known. (Vacuolaria, Fig. I3.)

V. Chromomonadina, cells single or in colonies; structure various, no plasma-membrane. Most of the numerous forms have one or two brown chromatophores and the nutrition is holophytic.

The last three groups with coloured chromoplasts suggest affinities with Algae, and Klebs in 1893 suggested an undefined connexion between the two green groups and the Chlamydomonads. The affinity between the Chromomonadina and certain groups of brown Algae does not admit of much doubt, and the nature of this affinity, on which recent work has thrown new light, will be considered in Section V.

The Euglenoidina are a rather specialized group which does not obviously lead to the Chlamydomonad type. The 
Chloromonads are nearer the latter but the cell-type with many yellowish-green chloroplasts is different, and recently a definite affinity has been suggested between these Chloromonads and a special group of green Algae (cf. Sect. IV). It seems to me then most reasonable by exclusion to derive the Chlamydomonads directly from the Protomastigina. As transitional forms we have Pyramidomonas, and Polyblepharis which Wille places in the Chlamydomonadaceae, but which though little known seem to be somewhat more primitive than Chlamydomonas and almost devoid of a cell-wall. Possibly they have been derived from green forms among the Chromomonads, but these suggestions must suffice here.

It appears that no organisms of preponderating plantcharacters have been evolved from the Euglena type. Its bright green colour and its power of holophytic nutrition superficially suggest an algal nature, and these with its welldeveloped plasmatic membrane and its paramylum-grains, which though not starch are an allied substance, seem to show that it has evolved from the Protomastigina in the plant direction, so to speak, or rather in a parallel direction. Still, by a consensus of the critical characters, it is a Flagellate beyond question. Closely allied to Euglena are some colourless forms, and Zumstein ('99) has just shown that Euglena gracilis itself may exist as a colourless saprophytic form. He finds that if a pure culture of Euglena gracilis be placed in a sugar-solution in the dark it multiplies abundantly and may become quite free from chlorophyll. When the organisms are replaced in pure water in the light, the culture develops chlorophyll and becomes green again and assimilates carbon dioxide. Thus either a saprophytic or holophytic nutrition can be maintained. Grown in the light in a medium rich in nutritive matter Euglena gracilis is, according to the author, colourless, which suggests that it prefers a saprophytic nutrition and only develops chlorophyll in order to obtain carbon by assimilation of carbon dioxide when other sources are scanty. Here we have the spectacle of a single species lightly passing backwards and forwards over the supposed dividing line. 
between two opposed methods of nutrition, the algal and the fungal, just as it may happen to be well fed or not.

Bohlin ('97 a) has described a similar case of alternative nutrition for Chloramoeba which belongs to a different class of Flagellates, so that in the hypothetical transition from the colourless Protomastigina to the Chlamydomonads, the necessity for developing chlorophyll is not a serious difficulty, in the light of these phenomena.

Just as green organisms occur among the Flagellata so colourless forms are found among the lower Algae. There should be really no more objection to letting such colourless forms take their place in the respective families to which a consensus of their characteristics entitles them, than is made as to the position of the chlorophyll-free Flowering Plants.

Chlamydomonas possesses one species, Chl. hyalina, which is, apparently, characteristically colourless and saprophytic. Further, related to Chlamydomonas, there exists a small group of colourless organisms of which Polytoma uvella is the best known. These have been carefully monographed by Francé ('94). They have the cell-structure of the Chlamydomonad type and starch is found in the cells, but they have a thick or thin out-standing wall. They divide by transverse or oblique divisions into groups of four or eight daughter-cells, usually while in the motile stage. Conjugation of gametes (indistinguishable from vegetative cells) has been observed. This group has thus all the critical characters of the Chlamydomonads except the green colour. Early observers of course classed them as animals. Dangeard ('88) proved that their nutrition was saprophytic and that their cell-wall prevented any ingestion of solid particles. It seems clear that they form a little family of which all the forms are saprophytic, and that they have probably evolved from some one green organism of the Chlamydomonad type. This necessitates their being placed as a sub-family in the Volvocaceae. They show certain resemblances to a special group of colourless Flagellates, and it is a theoretical possibility that a saprophytic organism of preponderating plant-characters might be evolved from a 
colourless Flagellate without any green forms being involved at all.

One other interesting organism of this nature (Sycamina) has been described by Van Tieghem ('80). This seems to be a colony of the complexity of Volvox, but, though blackish, quite devoid of chlorophyll. Its methods of reproduction are unknown, so that it can only be doubtfully suggested that it must stand to the Volvocineae in some such relation as Polytoma does to the Chlamydomonadeae.

All these colourless forms were excluded by Wille from his Volvocaceae, but further investigation of their characters and nutrition necessitates their inclusion in the group. See p. 649.

From this outline of the possible Flagellate origins of the primitive Chlorophyceae we may pass in the next section to consider a special case, in which it has been proposed to create an independent phylum of green Algae and to derive it from the Chloromonadales.

\section{SECTION IV. Heterokontae.}

Borzi ('89) proposed to group together into one special cohort-Confervales Bz.-certain forms of the Chlorophyceae which had been previously distributed among various groups. This idea he elaborated in his well-known Studi Algologici ('95), and also placed in the group several new genera discovered by himself. The characteristics of this cohort are essentially cytological. All cells contain discoid yellowish-green chloroplasts which are usually numerous and which lack pyrenoids. The stored-up product of assimilation is not starch but some fatty substance. The zoospores have also discoid chromatophores, typically two lateral ones, and generally only one cilium.

The members of this cohort are unicellular, filamentous or coenocytic, and so, as with the Chlorophyceae in general, the included forms are an ascending series from the structural point of view. The lower ranks of this new cohort include the Sciadiaceae, which are practically the Characieae of Wille, consisting mostly of unicellular forms attached by the base, 
as Ophiocytium (including Sciadium), Peroniella, Characiopsis, $\mathrm{Bz}$., Chlorothecium, Bz., and Mischococcus which previously had been in the Tetrasporaceae. The genus Conferva is also included here, and on the above characteristics is separated widely from Microspora which has none of them, but with which it had always been closely associated. The higher ranks of this cohort include three rather divergent types, Bumilleria, Botrydiopsis and Botrydium.

In 1897 Bohlin published an interesting paper containing a detailed study of the cytological characters of this group.

With regard to the structure of their cell-walls it had long been known that filaments of Conferva and Microspora break up across the middle of the cells into short cylindrical units consisting of the halves of two adjacent cells with a septum separating them. These are generally known as H-pieces from their appearance in optical section. Those of Microspora are homogeneous and of pure cellulose, but in Conferva (Fig. I4, $a$ ) they consist chiefly of pectic acid derivatives, and on swelling with potash show a special layered structure. On investigating filaments in all stages of division the growth of the cell-wall revealed a new type. The unit of growth consists of the halves of two adjacent cells, and thus the two halves of any given cell are of different age. On transverse division the new septum with the new ring-thickening at its periphery constitutes the starting-point for a new $\mathrm{H}$-unit, and while it thickens by obvious apposition layers, these also extend and elongate the cells on either side of the septum and so push two older units apart. In the diagram of the swollen wall structure in Fig. $14, b$ is a young cell and $c$ an old one. Considerable interest attaches to this procedure in itself, but this is much increased on its being shown that Ophiocytium, which Borzi had brought from a far-off family to join Conferva, possesses an interesting variation of this very type of growth. Ophiocytium when mature is a long curled cylindrical plurinucleate single cell which breaks across just near the top to liberate spores. This top cap is found to be the unaugmented half of the originally very short cell. 


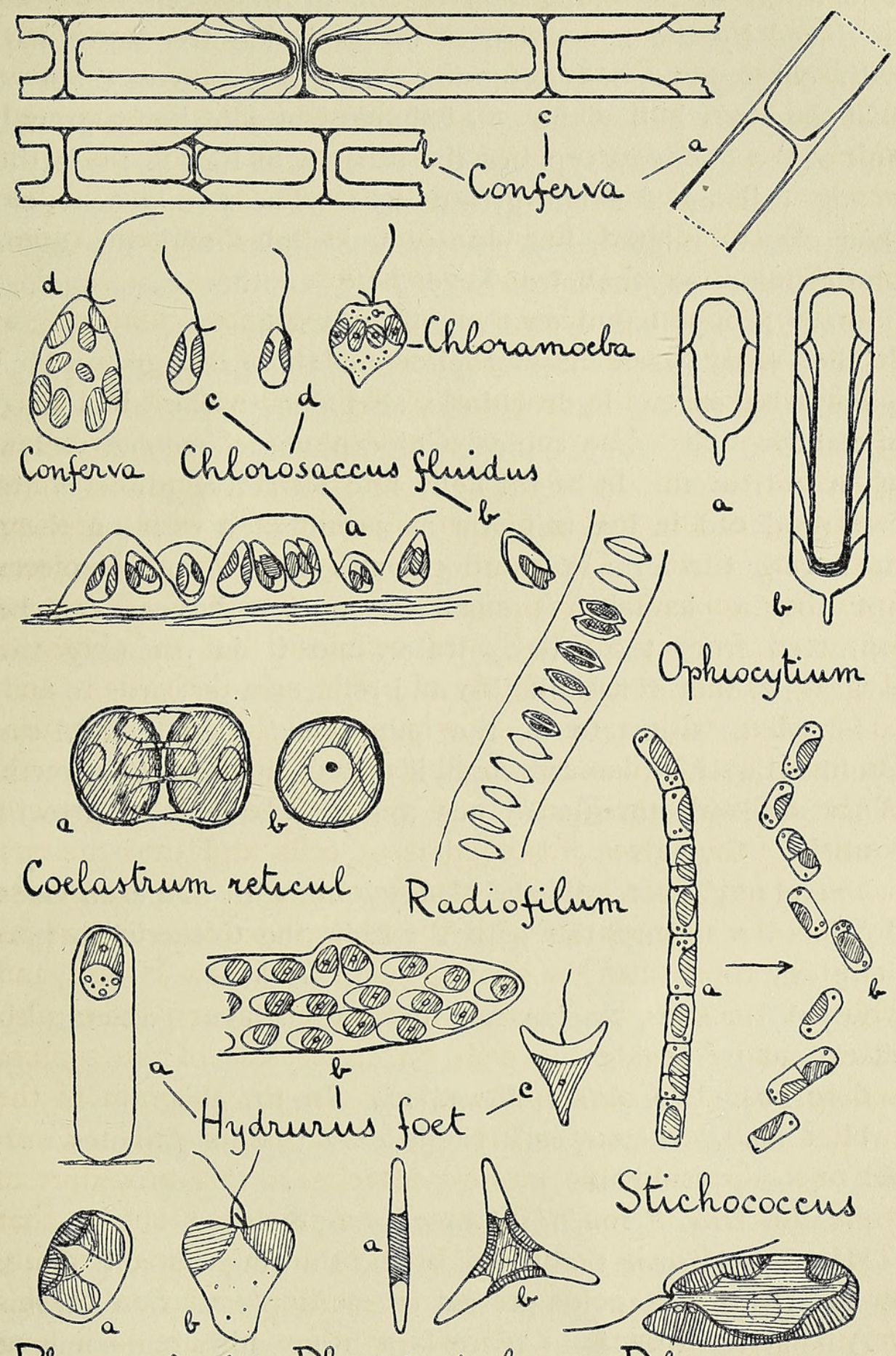

Phoocystisglol. Phooodactylon Rhodomonas

Fig. I4.

Y y 2 
The whole of the elongation of the growing cell has been produced by the apposition of layers inside the lower half with cotemporaneous extension and elongation of tnem so that the lower half of the cell behaves just like half a growth unit of the Conferva type (cf. the schema in Fig. I4; $a$ is the young cell and $b$ a half-grown cell). The two genera are thus closely related, but one is unicellular and the other pluricellular, so that we have here another case against primary groups based on these characters.

The yellow-green chromatophores of this group give a bluc odour with strong hydrochloric acid due to the abundance of xanthophyll, while typical Chlorophyceae become yellow when so treated. In bright light, fine refractive granules are first produced in the cell, and as assimilation goes on these run together to form large oil-globules, soluble in chloroform but not in alcohol. A small amount of hexose can be extracted from the cell by water, and it is probably the earliest product of assimilation and reduced afterwards to fat.

Vaucheria seems to be the only green Alga outside the Confervales which has chlorophyll possessing these characters. What phylogenetic significance this may have is at present doubtful.

The very close relation of Ophiocytium with Conferva leads Bohlin to rearrange the genera within the Confervales into three families.

I. Confervaceae, thallus uni- or multicellular, gametes biciliate, no pyrenoids.

Conferva, Ophiocytium, Bumilleria, Botrydiopsis.

II. Chlorotheciaceae, cells single or a thallus, gametes uniciliate, no pyrenoids.

Mischococcus, Peroniella, Characiopsis, \&c.

III. Botrydiaceae, thallus unicellular showing root and shoot, multinucleate, pyrenoids present in young plant. Botrydium.

Among the Flagellata there is a form which has some of the Confervales characteristics, namely a number of discoid, yellow-green chloroplasts without pyrenoids. This is the genus Vacuolaria (Cienkowski, '6i) (Fig. 14) of the Chloro- 

ERRATUM.

Vol. XIV, p. 674 , line II, for odour read colour

Annals of Botany. 
monadina. Not much was known about it, and as a simple mouthless green form Klebs had suggested that it might be a link between the colourless Flagellata and the Chlamydomonads. None of the Chlamydomonads, however, have these cytological characters, so that this type seems to complicate the matter rather than simplify them.

In 1897 Lagerheim discovered a similar but new genus, Chloramoeba (Fig. I4), the life-history of which was adequately investigated by his pupil Bohlin ('97). This has a roundish body, no wall or plasmatic membrane, a contractile vacuole at the fore end, a central nucleus, 2-6 discoid chloroplasts of a yellow-green colour, and two cilia, one twice as long as the body and the other quite short and often curled back against the body so as to be invisible.

The body exhibits marked amoeboid movement. The chloroplasts give a blue colour when treated with strong hydrochloric acid, as do those of the Confervales group, and the assimilation product, as in that group, is an oil, insoluble in alcohol.

Resting cells may arise by the encystment of solitary motile cells, but no Palmella-stage. This organism then is a typical Flagellate, while Vacuolaria, which divides in a palmelloid mucilaginous resting condition, exhibits somewhat more vegetal characters (Fig. 14).

Further, while Vacuolaria is always green, Chloramoeba can adapt itself to a saprophytic nutrition in the dark, like Euglena, and become quite colourless. On transferring the organism to the light, in water free from organic material the yellowgreen colour is regained, as has been already mentioned.

The group of Chloromonadina is then well established with the primitive form Chloramoeba and the more vegetal form Vacuolaria, and the points of similarity in cell structure with the Confervales are striking and suggestive of some affinity, if primary importance is to be attached to cytological characters.

Within a year a paper of great interest was published by Luther ('98), in which he described a new organism, Chloro- 
saccus, which seems beyond doubt to connect up these green Flagellates in a direct line with the Confervales. Chlorosaccus (Fig. I4, $a$ ) has a superficial resemblance to Tetraspora, but is of a yellow-green colour and grows submerged, and attached to water-plants, forming irregular hollow mucilaginous spheres.

The individual cells in the mucilage are pear-shaped, with the smaller end outwards, and when division is rapid they are found grouped in fours, but this arrangement is soon obscured.

The chromatophores are parietal disks, several in number, and they give the blue colour with hydrochloric acid. There are no pyrenoids. When the cells are alive there appears to be no cell-wall within the mucilage, but after death a shell of wall can be made out which is thick at the superficial small end and very thin at the big central end, or even incomplete so that it may spring off the dead protoplast (Fig. 14, $b)^{1}$. This structure is of great interest as a transition between the unwalled Flagellate type and the walled vegetal type, and its greater density at the exposed end agrees with $\dot{a}$ priori considerations. Staining shows that the wall is of a pectic nature, as in Conferva, and no cellulose reactions can be detected.

The cell-division takes place parallel to the long axis of the individual cells which is a Flagellate character, and four daughter-cells arise nearly simultaneously. Individual cells may enlarge to form resting akinetes with thick walls, and these drop out of the colony.

The greater part of the existence is thus non-motile, but zoospore-formation takes place under suitable conditions. The zoospores, at first pear-shaped, escape through the mucilage, and when free their naked mass contracts to a rounder form. Each has two lateral discoid yellow-green chloroplasts, and doubtfully an eye-spot. At the fore end are two cilia, one three times the body-length, projecting forwards, and the other less than the body-length, thin and bent. If the zoospore be killed with iodine (Fig. 14, c), both

1 Pilidiocystis, Bohlin ('97 c) has a somewhat similar wall. 
cilia are clearly seen, but if killed with osmic acid (Fig. $14, d$ ), the short one curls back tightly against the body, and is invisible. After a few hours' swarming the zoospores come to rest, secrete mucilage round them, and begin dividing to form a new colony. There is no sexual reproduction.

The relation of Chlorosaccus to Chloramoeba seems clear. Its Tetraspora-like aggregation and the shortness of the motile stage are plant characteristics, while its incomplete wall and absence of sexual reproduction are Flagellate characteristics. Luther, attaching much importance to the vegetative division being parallel to the long axis of the cell, allows this to weigh down the balance and classes it as a Flagellate in the same family with Vacuolaria; but it seems to me that he overrates the importance of this, since Dill has shown that the lower Chlamydomonads divide in this way, and as division must go so if the colony-membrane is to expand tangentially without cell-displacement. Perhaps then it may be ranked as an Alga rather than a colonial Flagellate. At all events it is very nearly balanced on the line between the two classes, and only serves to illustrate the absence of absolute cleavage-lines and how in a difficult case one's decision may almost be called 'subjective.'

The great stumbling-block in the way of deriving the Confervales from a Chlorosaccus type, just as the Confervoideae are derived through a Tetraspora type, was obviously the difference in the ciliation of the zoospores.

The zoospores of the typical genus Conferva have several discoid yellow-green chloroplasts, as analogy would indicate, but they are described by Klebs and other good observers as having only one cilium-a long one. Luther made the important discovery that they really have a second short cilium, and if they have been killed with iodine this can be seen standing out from the body (Fig. I4, $d$ ). Most fixing reagents, however, cause this one to curl back against the body and to become invisible. He found also that just the same holds good for Botrydiopsis, another genus of the Confervales which he investigated. This character then appears, 
with the other cytological characters, to hold right through from the typical Flagellate Chloramoeba to these high filamentous Algae.

Luther proposes to regard these forms as evolved from the Chloromonadina of the Flagellates and to take them therefore right out of the true Chlorophyceae which are regarded as evolved from the Protomastigina group of the Flagellates, and to make a separate main group of them equivalent with that of Chlorophyceae. For this he proposes the name of Heterokontae, and divides it up into a Flagellate group Chloromonadales with the ascending series of forms:-Chloramoeba, Bohl., Vacuolaria, Cienk., Chlorosaccus, Luther, and an algal series Confervales, Bz.; containing the families Confervaceae, Chlorotheciaceae and Botrydiaceae.

The evidence for this separation seems adequate, and it is an immense advance in the direction of a natural phylogenetic classification of the green Algae. Possibly other series of forms may also be removed from the Chlorophyceae and have an independent evolution attributed to them, thus rendering the Algae still more polyphyletic.

The relation between the green Algae and the Flagellates may be briefly summarized thus. The green Euglenoidina give rise to no algal forms, the green Chloromonadina have given rise to the Heterokontae series of green Algae, while the colourless Protomastigina have probably produced the Chlamydomonad type and all that has arisen from it.

In conclusion I propose to give a short account of the relation between the brown Flagellates and some of the newly described forms of the Phaeophyceae.

\section{Section V. Primitive Phaeophyceae.}

Not many years ago (see Kjellman ('91) in Engler and Prantl) the simplest structural forms recognized amongst the Phaeophyceae were elaborately branched filaments such as occurin the marine Ectocarpus and the fresh-water Pleurocladia; Klebahn ('95), Wille ('95). 
In the absence of any primitive forms any theory of the origin of this group was then simply a matter of speculation, but a possible derivation from brown Flagellate organisms was suggested as a parallel with the origin of the green Algae. Links to substantiate such a line have now been discovered, and this theory may be considered as at the present time firmly established. It is of the greatest interest to note that the intermediate organisms show a striking parallelism in grade with those in a similar position on the phylum of the Chlorophyceae.

We have thus a rising series :-

I. Organisms which are generally admitted to be Flagellata, as Synura, Uroglena, and Hydrurus.

2. Phaeocystis, which approaches the border line of the Algae.

3. Phaeococcus and Entodesmis, which correspond to the Tetrasporaceae among the green Algae.

4. Phaeodactylon and Stichogloea, parallel with the Pleurococcaceae.

5. Phaeothamnion, corresponding to a very simple type of Confervoideae and leading to-

6. The typical Phaeosporeae which have the unilateral swarm-spore and so-called uni- and multilocular sporangia.

At the present time most of these intermediate groups are very imperfectly known, but taken together they seem to form a bridge over the gap, which is sufficiently strong to carry this hypothesis of the evolution of the Phaeophyceae from Flagellata quite independently of the evolution of the Chlorophyceae and the Heterokontae.

We will go briefly through some of the points of interest in this series of forms.

It is a general character of this phylum that the chromatophores are brown, and the product of assimilation neither starch nor oil, and that the cilia of the motile cells are usually unsymmetrical.

The first group of these forms belongs to the sub-family Chrysomonadina of the Chromomonadina. Here we find 
many unicellular naked brown Flagellates and some well defined colonial forms, of which we may mention three.

Synura (Klebs ('93), Schmidle ('99)) consists of a motile colony of about ten heart-shaped brown cells, each biciliate and grouped as in Pandorina, with an investing mucilage through which the cilia protrude. The cells are all naked and the colony is not a true coenobium, as it grows to mature size by division of its cells from a single free motile cell.

Uroglena (Klebs ('92), Iwanoff ('99)). The cells are of the same type, but the colony resembles $V$ olvox in having a large hollow central space full of mucilage and a number of ciliate cells round the periphery; but the colony may divide into two by constriction. On the phylum of brown organisms these colonial forms which resemble the Volvocaceous types of aggregation are found to be made up of true Flagellate cells, i. e. naked and dividing longitudinally, instead of true algal cells as on the green phylum. In spite of this, Bütschli ('86) grouped these two families together in his Phytomastigoda.

Hydrurus (Fig. I4, $a, b, c$ ), long thought to be a green Alga, was by Klebs ('93) shown to consist of a number of unciliated cells each with one phaeoplast and devoid of a cell-wall, but all imbedded in a branched cylindrical mucilaginous matrix which may be $30 \mathrm{cms}$. long and yet branches with a regularity rarely met with among the Algae ${ }^{1}$. The cells are single at the apices of the branches and form a peripheral layer lower down $(b)$. The morphological differentiation of the branchsystem found here, is unparalleled in such a loose aggregation of apparently unconnected cells : thus, the opposition of base and apex is very marked and the basal cells never give rise to branches; the centrally situated cells seem to have lost the power of division, and growth in length is entirely conducted by the single apical cells, the branching being usually monopodial.

Thus while the whole is clearly a colony of unicellular units, it has yet attained the morphological correlations of intimate multicellularity. The apical cells characteristically divide

1 Phaeodermatium is generally held to be an unbranched cushion-like form of a Hydrurus colony. 
longitudinally, and one half becomes the new apical cell while the other is displaced below it.

For reproduction the cells become free and swarm as tetrahedral zoospores with a colourless ciliate apex $(c)$. These subsequently come to rest, attach themselves by the clear apex and secrete a long mucilaginous column so as to push themselves up on a wide stalk $(a)$. The base of the cell is thus directed to the apex of the stalk, and this relation is maintained all through the branching system. Lateral branches arise acropetally by peripheral cells, at intervals, taking on apical growth. Of course there is no sexual reproduction. The cells contain no pyrenoids and the product of assimilation is a highly refracting liquid, the so-called 'leucosin.' The essential point which distinguishes Hydrurus from other colonial Flagellates is that the whole organism is non-motile in the main part of its existence. It only reverts to its ancestral motility at the swarm-spore stage, and this of course for biological advantage in spreading the species. Now this nonmotility is characteristic of the plant-type, and those who attach absolute importance to this consider that Hydrurus has evolved over the border-line and must be considered to be an Alga, though it is clearly on a little branch-phylum of its own and not on the main Phaeophyceae-phylum. Its remarkable morphological differentiation supports this. If, however, motility is to be the absolute test it is clear that conversely all the Volvocaceae must be regarded as Flagellates ; Bütschli, Scherffel ('00). Adopting a consensus of characteristics as our standard, we may keep the Volvocaceae as plants and yet hesitate to call Hydrurus one.

Phaeocystis. Lagerheim ('96), Scherffel ('98), ('00). The two known species of this genus form mucilaginous spherical colonies visible to the naked eye and floating motionless in the sea. The centre of the colony consists of thin mucilage, and the naked round cells with their two phaeoplasts are sparsely scattered over the denser periphery of this very fragile organism. Contractile vacuoles, eye-spots and pyrenoids are absent, and leucosin is the product of assimilation. Phaeocystis was first 
described as a species of Tetraspora, which it superficially resembles, and it reproduces by zoospores.

The individual cells are non-motile, and the mucilage may serve to float them by entangling air, or to protect them from small larvae. In Fig. 14, $a$, a vegetative cell with two bandphaeoplasts and a globule of leucosin is shown, and in $b$ a zoospore which has the very unusual equipment of three cilia, two long and one short, and also has its chromatophores at the anterior end.

Here again the essential non-motility is held by Scherffel to put this among the Algae, but Lagerheim and most authorities place it among the Flagellata on account of its naked cells and probable longitudinal division. The absence of cilia, eye-spot and vacuoles, however, seems to me to indicate a long established abandonment of the Flagellate type. The characters which Klebs so successfully drew up to differentiate between Flagellates and green Algae are not equally decisive between Flagellates and brown Algae, which indeed is only natural as they are independent evolutions. All speculators have so far tried to use the same sets of characters on both phyla. I would suggest that this should be abandoned, and that it should be recognized that on the brown phylum the evolution of colonial aggregates of increasing solidarity has gone ahead of the evolution of a type of individual cell which is definitely algal, compared with the relation of these two characters on the green phylum. Thus the majority of unicellular motile green organisms are Algae, while the majority of brown are Flagellata. Organisms of the Volvox, Pandorina, and Tetraspora type of aggregation are found to be algal (in cell-type) if green, and Flagellate when brown. This seems tenable and removes the difficulties of a rigid system, but shows how unreal and unimportant is the separation of the kingdoms. Rising higher on the phylum we come to organisms which have sufficient plant-characteristics to leave no room for discussion.

Phaeococcus (Borzi ('93)) consists of spherical cells walled and non-motile, of which four are imbedded in a gelatinous matrix 
(recalling Gloeocystis). They divide in all three directions and possess zoospores with unequal laterally inserted cilia. The conjugation of planogametes to form a zygote has been observed.

Entodesmis (Borzi ('92)) consists of elliptical, walled cells in tabulate mucilaginous colonies. The cells form zoospores with two unequal lateral cilia. These two genera have no Flagellate characters and are clearly of the status of the Tetrasporaceae.

Phaeodactylon (Bohlin ('97)) has a star-like cell with three arms in one plane and a central brown chromatophore. The cell-wall cannot be resolved into two pieces as with Diatoms. It floats freely in pools of brackish water and is considered to multiply only by vegetative cell-division. In Fig. I4, $a$ and $b$ represent aspects at right angles to each other.

Stichogloea (Chodat ('97a)) also multiplies only by vegetative division, and thus with the previous genus represents the Pleurococcaceae-type. The cells are ellipsoid and grouped in fours to form a mucilaginous colony.

Phaeothamnion (Lagerheim ('84)) brings us to thefilamentous brown Algae (corresponding with the green Confervoideae). It forms small tufts of slightly branched filaments growing attached in fresh water. Its discoverer, after some hesitation, placed it, in spite of its colour, in the green Confervoideae because he found its zoospores to have two equal apical cilia. This is accepted by Wille (' 90 ) in Engler and Prantl, but Borzi ('92) asserts that the zoospores have two lateral unequal cilia. Our new knowledge of primitive brown forms shows us that this character is not an absolute criterion. On general grounds later authorities place it on the brown phylum. Phaeothamnion also forms 'palmella' states.

Pleurocladia (Klebahn ('95), Wille ('95)) is a larger branched fresh-water brown Alga, and may be regarded as the simplest of those conforming to the long-recognized type with zoospores and gametes; and here we may leave this ascending series of brown forms on well-established ground.

While all the higher brown Algae are marine, it is perhaps 
A RCHEGON I A T AE

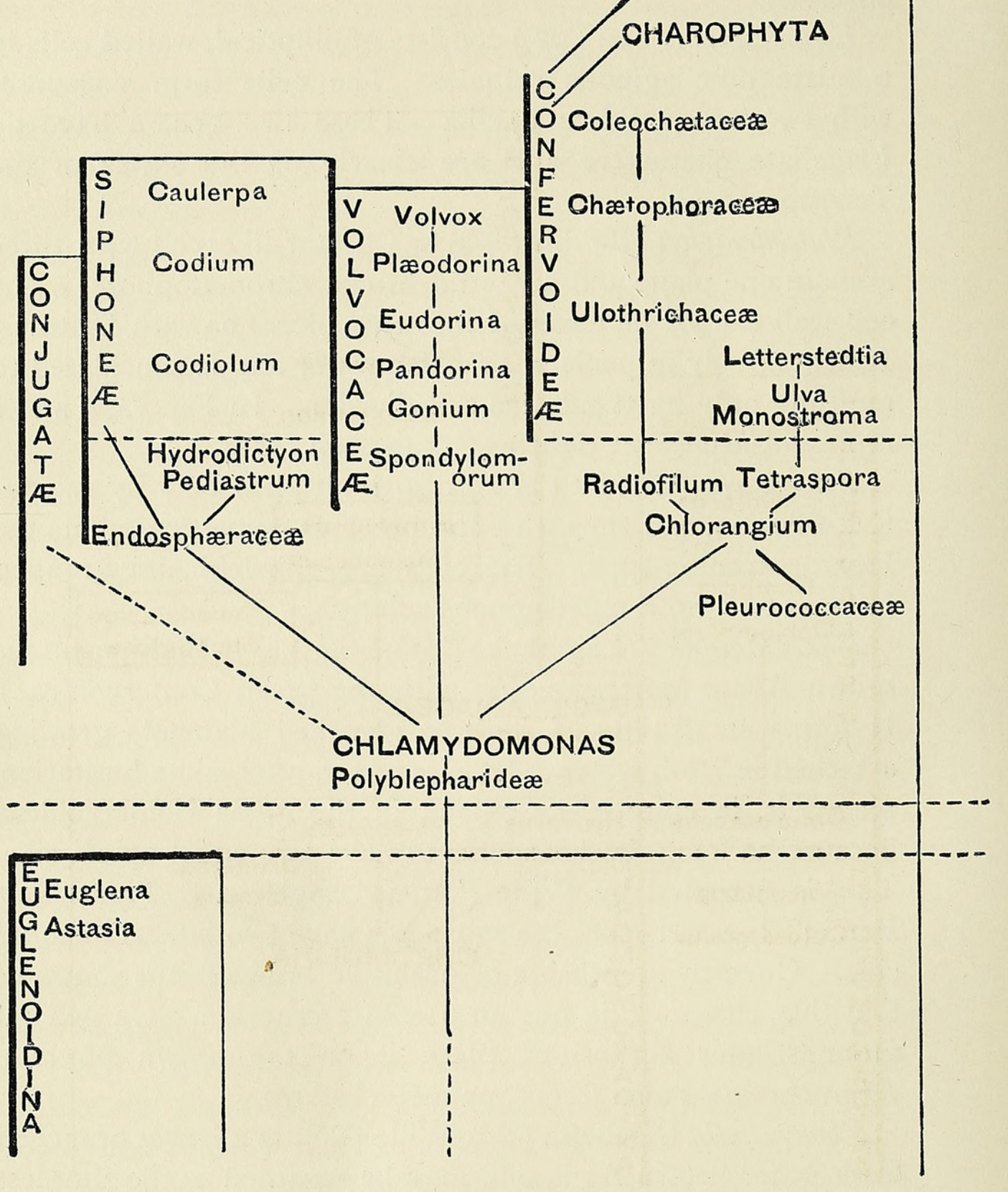

$\begin{array}{lllllllll}P & R & O & T & O & M & A & S & -\end{array}$ 


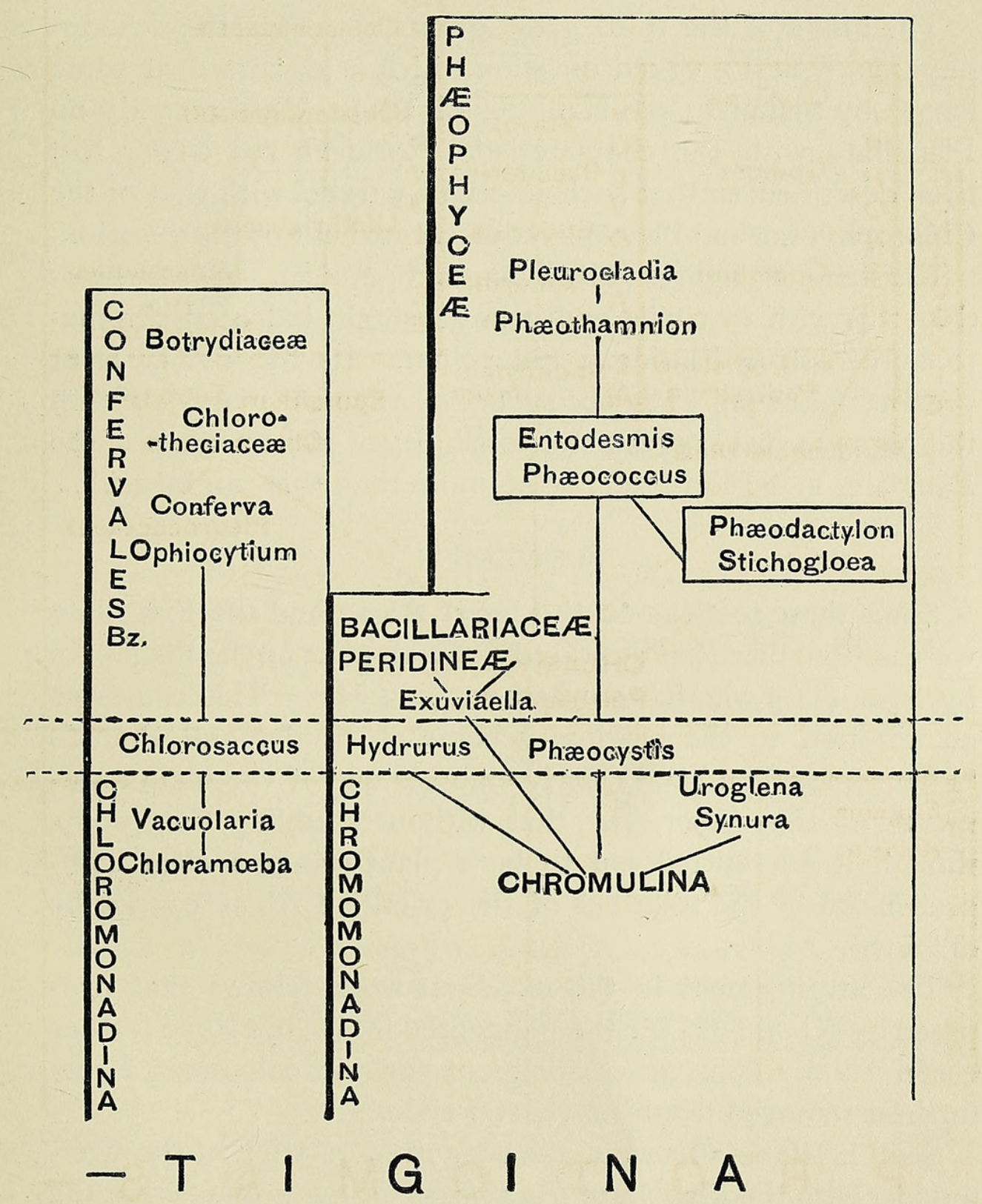


significant of the Flagellate origin that nearly all of the primitive forms inhabit fresh water.

The gaps in the series that we have gone through are too large to allow very precise phylogenetic speculation, but the schema on pp. 684,685 embodies the views of Scherffel, Lagerheim and Bohlin.

The origin of the third great group of Algae, the Rhodophyceae, is still a vexed question which is discussed at some length by Schmitz; see Hauptfleisch ('94). Until recently no Flagellate with the characteristic Floridean red colour had been described, so that such an origin, parallel with that of the Chlorophyceae and Phaeophyceae, seemed out of the question.

Karsten ('98) figures such a marine organism. Rhodomonas (Fig. 14) with two cilia and a large single indented chromatophore of true Floridean red colour. Its life-history is at present unknown. The occurrence of a typical Flagellate with this pigment just suggests the possibility of such an origin of the Bangiales and Florideae, but no more than this can be said.

\section{POSTSCRIPT.}

Since these sections on the lower Algae and the Flagellata were written there has appeared a new treatise on the Flagellata by Senn ('00), who has worked under Klebs. This comes as an addition to the original scheme of Engler and Prantl's 'Pflanzenfamilien,' and clearly enforces one of the main arguments of this paper, viz. that without studying this group, though it is admitted not to be a plant-group, a clear comprehension of the relations of the primitive Algae cannot be obtained.

The arrangement in this excellent work follows that proposed by Klebs ('92) for the pigmented forms, but some further useful subdivisions are carried out for the colourless forms furthest removed from the vegetal type.

Senn hesitates to accept the suggested relation of the Confervales with the Flagellate Vacuolaria on the grounds that the latter is too highly differentiated, but the simple hypothesis of a common ancestor destroys none of the interest of the theory. 


\section{BIBLIOGRAPHY.}

Blochmann, F., '85: Haematococcus Bütschlii (Verh. nat.-med. Vereins, Heidelberg, Bd. iii, I885).

BoHLIN, K., '97a: Zur Morphologie u. Biologie einzelliger Algen (Öfv. Kon. Vet.-Akad. Forh., 1897, No. 9).

'97b: Studier öfver nägra slägten af Alggruppen Confervales Bz., with a German résumé (Bihang till K. Sv. Vet.-Akad. Handl., xxiii, I897).

97c: Die Algen der ersten Regnell'schen Expedition (Bihang till K. Sv. Vet.-Akad. Handl., Bd. xxiii, I897).

BoRzI, A., '89: Botrydiopsis, nuovo genere di alghe verdi (Boll. della Soc. ital. dei microscopisti, vol. i, I889).

'92 : Alg. aqua dolce della Papuasia (Nuova Notarisia, ser. $3^{a}, 1892$ ).

93 : Int. sviluppo sess. alc. Feoficee infer. (Atti Congr. Bot. Internaz., Genova, I892).

'95 : Studi algologici, fasc. ii. Palermo, 1895.

Bütschli, O., '86 : Mastigophora. Bronn's Klassen des Thierreiches, I883-86.

Chmielevsky, V., '90 : Über das Verhalten der Chlorophyllbänder in den Zygoten der Spirogyrarten (Bot. Zeitung, I89o).

Сhodat, '97 $a$ : Alges pélagiques des lacs suisses (Buil. de l'Herbier Boissier, tom. v, I897).

'97 $b$ : On the Polymorphism of the Green Algae and the Principles of their Evolution (Annals of Botany, xi, 1897).

Cienkowski, '67 : Über Palmellaceen u. einige Flagellaten (Archiv für Mikroskop. Anat., Bd. vi, 1867 ).

DANGEARD, P. A., '88: Rech. sur les algues inférieures (Ann. des sci. nat., $7^{\ominus}$ sér., tom. vii, I 888 ).

'99: Mémoire sur les Chlamydomonadinées (Le Botaniste, $6^{\ominus}$ sér., I 899 ).

DAvis, '94 : Euglenopsis (Annals of Botany, viii, I894).

DILL, O., '95 : Die Gattung Chlamydomonas u. ihre nächsten Verwandten (Jahrb. f. wiss. Botanik, xxviii, I895).

Ehrenberg, Chr. G., '38: Die Infusionsthierchen. Leipzig, 1838 .

FrancÉ, R., '92: Zur Systematik einiger Chlamydomonaden (Termesz. Fuzetek., 1892 ).

'94: Die Polytomeen (Pringsheim's Jahrb. f. wiss. Botanik, xxiv, r 894).

Goroschankin, J., '90: Beiträge z. Morphologie u. Systematik von Chlamydomonaden, i. (Bull. Soc. Imp. d. sc. nat., Mosc ou, tom. iv, I890).

- '91 : Beiträge zur Morphologie und Systematik von Chlamydomonaden, ii. (Bull. Soc. Imp. d. sc. nat., Moscou, tom. v, I891).

Hauptfleisch, '94: Bangiales (Engler u. Prantl, Pflanzenfamilien, r 894).

Iwanoff, '99: Beiträge z. K. d. Chrysomonadinen (Bull. de l'Acad. de St. Pétersbourg, $5^{\ominus}$ sér., tom. $x i, 1899$ ).

KARSTEN, '98: Rhodomonas baltica (Wissensch. Meeresuntersuchungen, Bd. iii, Heft 2, Kiel, I898).

KJellman, F. R., '91: Phaeophyceae (Engler u. Prantl, Pflanzenfamilien, I89I).

Klebahn, '95 : Pleurocladia lacustris (Ber. d. deut. bot. Gesell., xiii, I895). 
KLEBS, G., '93 : Flagellatenstudien, Th. i. u. ii. (Zeitschrift f. wissensch. Zoologie, Bd. lv, I893).

'96: Die Bedingungen der Fortpflanzung bei einigen Algen und Pilzen. Jena, 1896 .

KLerCKer, J., '96: Über zwei Wasserformen von Stichococcus (Flora, 1896).

LAGerheim, G., '84 : Über Phaeothamnion (Bih. till K. Sv. Vet.-Akad. Handl., Bd. ix, 1884).

'96: Phaeocystis Poncheti, ein Plankton-Flagellate (Öfv. K. Vet.Akad. Forhandl., I 896 ).

Luther, A., '98: Chlorosaccus, n. g. (Bihang till K. Sv. Vet.-Akad. Handl., Bd. xxiv, I898).

NAEgeli, C., '49: Gattungen einzelliger Algen (Neue Denkschr. d. allg. Schweizer. Gesell. f. d. Naturwiss., Bd. x, I849).

Scherffel, A., '99 : Phaeocystis globosa, n. sp. (Ber. d. deut. bot. Gesell., xvii, I899).

'00: Phaeocystis globosa, nebst einigen Betrachtungen über die Phylogenie niederer brauner Organismen (Wissensch. Meeresuntersuchungen, Bd. iv, Abt. Helgoland, i, 1900).

SChmidle, '93: Chlamydomonas Kleinii (Flora, I893).

'99: Über einige in Pite Lappmark gesammelte Algen (Bihang till K. Sv. Vet.-Akad. Handl., xxiv, No. 8, I899).

SENN, G., '99 : Über einige coloniebildende einzellige Algen (Bot. Zeitung, June, I 899).

'00: Flagellata (Engler u. Prantl, Pflanzenfamilien, 1900).

SNow, Julia, '98 : Pseudopleurococcus (Annals of Botany, vol. xiii, 1898).

Stern, F., '78: Der Organismus der Infusorien. iii. Flagellaten. Leipzig, 1878.

Van Tieghem, '80 : Sycamina nigrescens (Bull. Soc. bot. de France, I 880).

De Toni, J. B., '95: Sylloge Algarum, vol. iii. Fucoideae. Palermo, I 895.

WAGER, H., '99 : On the eye-spot and flagellum in Englena (Jour. Linn. Soc., Zoology, vol. xxvii, 1899).

Wille, N., '90: Chlorophyceae (Engler u. Prantl, Pflanzenfamilien, I890).

'95 : Pleurocladia lacustris (Ber. d. deut. bot. Gesell., xiii, I895).

Zumstein, '99 : Über Euglena (Pringsheim's Jahrb. f. wiss. Botanik, xxiv, i 899). 


\section{$2 \mathrm{BHL}$ Biodiversity Heritage Library}

Blackman, Frederick Frost. 1900. "The primitive algae and the flagellata. An account of modern work bearing on the evolution of the algae." Annals of botany 14, 647-688. https://doi.org/10.1093/oxfordjournals.aob.a088798.

View This Item Online: https://www.biodiversitylibrary.org/item/238259

DOI: https://doi.org/10.1093/oxfordjournals.aob.a088798

Permalink: https://www.biodiversitylibrary.org/partpdf/318605

\section{Holding Institution}

Smithsonian Libraries

\section{Sponsored by}

Biodiversity Heritage Library

\section{Copyright \& Reuse}

Copyright Status: Not in copyright. The BHL knows of no copyright restrictions on this item.

This document was created from content at the Biodiversity Heritage Library, the world's largest open access digital library for biodiversity literature and archives. Visit BHL at https://www.biodiversitylibrary.org. 